\title{
Microscopic Techniques to Evaluate Technological Differences Among Native Pre- hispanic Populations from the Low Paraná River, Argentina.
}

\author{
Romina Silvestre ${ }^{1,2 *}$, Maricel Pérez ${ }^{1,3}$, Natacha Buc ${ }^{2,3}$, Daniel Loponte ${ }^{2,3}$ y Alejandro Acosta ${ }^{2,3}$ \\ ${ }^{1}$ Secretaría de Investigación y Posgrado, Facultad de Humanidades y Ciencias Sociales, Universidad \\ Nacional de Misiones (UNaM). \\ ${ }^{2}$ Consejo Nacional de Investigaciones Científicas y Técnicas (CONICET). Posadas, Argentina. \\ ${ }^{3}$ Instituto Nacional de Antropología y Pensamiento Latinoamericano, Buenos Aires, Argentina. \\ *corresponding author: romisilvestre@gmail.com
}

Pre-hispanic technology used by human populations that inhabited the low Paraná wetland (LPW) during the Late Holocene was mainly based on the exploitation of different raw materials such as clay, lithic, bone and shell $(1,4,5,7)$. Similar strategies associated with a fluvial economy are recorded from early ( 2300 years BP) to late contexts $(\sim 500$ years BP) although material variability is also detected. This region comprises a large area of $320 \mathrm{~km}^{2}$ with a high density of archaeological sites that shows material properties suggesting a process of increasing social complexity and intensification on the exploitation of the environment. In this context, different groups extensively employed pottery vessels, among their processing and consuming strategies of food resources. At the same time, artifacts manufactured on lithic and bone raw materials were part of a sophisticated, complex and costly capture and processing equipment that enabled the efficient handling of resources (8).

The archaeological record shows that a fragmented social environment existed before the arrival of the Spaniard conquerors in the Río de la Plata. A significative concentration of groups with a hunter gatherer economy coexisted with Amazonian horticulturalists, known as guaraníes. Studies on technological strategies show significant technological and technical differences among both social groups. Through different microscopic techniques we obtained information about composition, manufacture techniques, and raw material employment. The aim of this paper is to evaluate the variability through different samples in a regional scale.

Pottery was studied through thin sections in a petrographic microscope working with 10x. Bone and lithic use-wear analyses were performed with two metallurgical microscopes working between 50x and 200x. An Olympus BX51M and Olympus BX60M microscopes with an Infinity Analyze softwares were used to acquire images on a computer attached to the microscopes. Also, a stereomicroscope was used to register features that requires three-dimensional observations and perception of depth working between 10x and 40x. Shell ornaments were observed whit the stereomicroscope (50x). A Philips 515 scanning electron microscope with EDX was used to analyze body ornaments like beads manufactured on green rocks.

Microscopic techniques allowed us to evaluate different aspects of archaeological materials. Thin sections show differences on hunter gatherers and horticulturalist pottery fragments, i. e. the materials used as temper (Figure 1). Use-wear analysis on lithic artifacts show that while hunter gatherers mainly used their scarce lithic raw material to produce bone artifacts (7), horticulturalist groups have a wide variety of worked materials, mainly vegetables (Figure 1) (9). On the other hand, bone artifacts show that while guarani groups had an expedient technology with almost no use (2), hunter gatherers had a wide variety of artifacts that were extensively used and imply the employment of specific manufacture techniques 
(1) (Figure 1). Finally, shell ornaments are only recorded on hunter-gatherer sites and display morphological variety. However, microscopic analysis show that similar use and manufacture techniques were employed across the landscape (3).

We conclude that, microscopic techniques are a fundamental interdisciplinary tool to solve archaeological questions not only on research problems, but also to improve our knowledge on conservation techniques of different materials.

\section{References}

[1] N. Buc. "Tecnología Ósea de Cazadores-Recolectores del Humedal del Paraná Inferior. Bajíos Ribereños Meridionales". Eds. D. Loponte and A. Acosta. (Instituto Nacional de Antropología y Pensamiento Latinoamericano, Buenos Aires). (2012) p. 272.

[2] Buc, N., Pesquisas, Antropología 73(2017), p. 79.

[3] N. Buc, A. Acosta D. Loponte. Comechingonia. (2018), In press.

[4] D. Loponte, "Arqueología del Humedal del Paraná inferior (Bajios Ribereños Meridionales)", (Instituto Nacional de Antropología y Pensamiento Latinoamericano, Buenos Aires) (2008) p. 480.

[5] M. Pérez. “Tecnología de Producción y Uso de la Alfarería Durante el Holoceno Tardío en el Humedal del Paraná Inferior”. unpub. PhD diss. (Universidad de Buenos Aires, Buenos Aires) (2016) p. 232.

[6] M. Pérez, R. Silvestre, N. Buc. Rev. Antrop. M. E. Ríos. 4 (2) (2018), p. 41.

[7] R. Silvestre, 2017. “Tecnología Lítica del Humedal del Paraná Inferior”. unpub. PhD Diss. (Universidad de Buenos Aires, Buenos Aires), p. 308.

[8] R. Silvestre, N. Buc, A. Acosta, D. Loponte. Comechingonia 17(1) (2013), p. 27.

[9] R. Silvestre, N. Buc, R. Montero. J. Archaeol. Sci. Rep. (2019), In press.
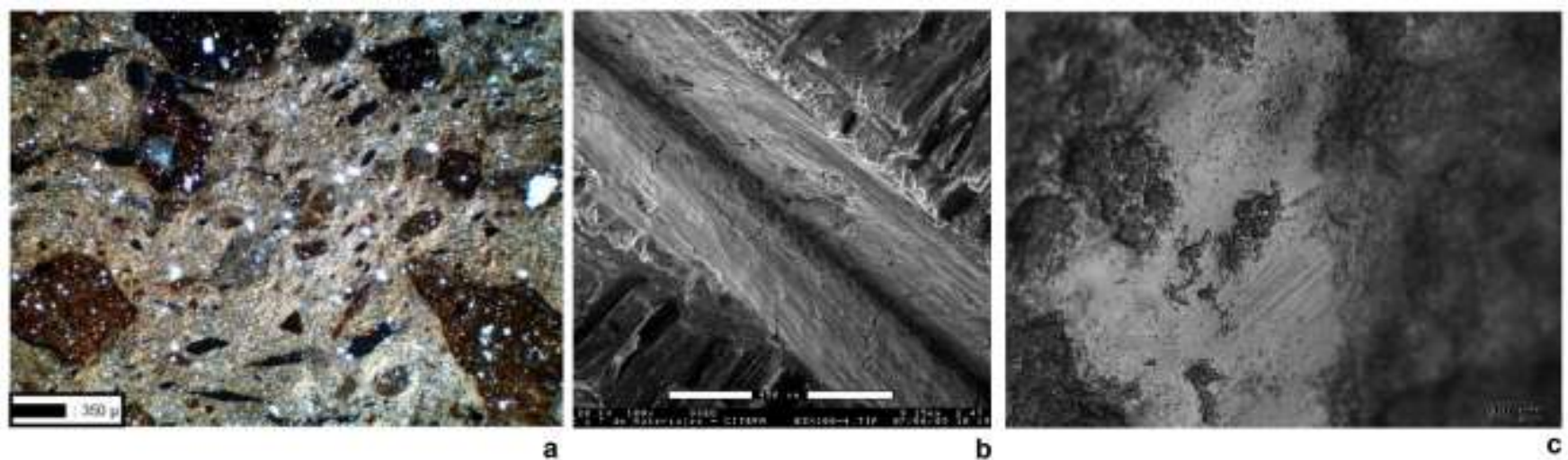

Figure 1. Different archaeological materials observed microscopically. a) pottery sherd with sherd fragments used as a temper, $\mathrm{A}^{\circ}$ Fredes, b) experimental bone with cutmark with lithic artifact, c) experimental lithic artifact with micropolish produced with Phormium tenax, 200x. 